Research Article Plant Genetics

\title{
Transference of multiple resistance to peanut through the development of cross-compatible complex hybrids of wild Arachis
}

\author{
Alessandra Pereira Fávero ${ }^{*}$ (D), Adriana Regina Custodio $^{2}$ (D), Naiana Barbosa Dinato ${ }^{3}$ iD, Ignácio José de \\ Godoy $^{4}$ (D), José Guillermo Seijo ${ }^{5}$ (iD and Marcos Doniseti Michelotto ${ }^{6}$ iD \\ ${ }^{1}$ Embrapa Pecuária Sudeste, São Carlos, SP, Brazil. \\ ${ }^{2}$ Embrapa Recursos Genéticos e Biotecnologia, Brasília, DF, Brazil. \\ ${ }^{3}$ Universidade Federal de São Carlos, São Carlos, SP, Brazil. \\ ${ }^{4}$ Instituto Agronómico, Campinas, SP, Brazil. \\ ${ }^{5}$ Universidad Nacional del Nordeste, Instituto de Botánica del Nordeste, Facultad de Ciencias Exactas y \\ Naturales y Agrimensura, Corrientes, Argentina. \\ ${ }^{6}$ Agência Paulista de Tecnologia dos Agronegócios, Polo Centro Norte, Pindorama, SP, Brazil.
}

\begin{abstract}
Peanut (Arachis hypogaea L.) is a tetraploid species with an A and B genome, while the majority of wild Arachis species are diploid with distinct genomes. In pre-breeding programs, one way to introgress interesting wild genes into peanut is by producing amphidiploids. This study aimed at the hybridization between distinct amphidiploids and their characterization, to combine high crossability with peanut, observed in some amphidiploids, with high pest and disease resistances observed in others. These new hybrids were called complex hybrids. Four amphidiploids previously obtained were crossed at four different combinations, and the derived complex hybrids were crossed with four peanut cultivars. Morphological, reproductive, chromosome complement, molecular markers for hybrid identification, phytopatological, and entomological characterizations were performed on the complex hybrids. All cross combinations resulted in complex hybrids. One complete complement of each diploid progenitor was confirmed in each hybrid. Plants of six distinct hybrid combinations were obtained between the complex hybrids and peanut. Based on morphological characterization, differences among progenies from distinct cross combinations were observed. Complex hybrids were considered more resistant to all diseases and pests than peanut cultivars. The simultaneous introgression of genes from four wild Arachis species into peanut was possible through the development of complex hybrids.
\end{abstract}

Keywords: Amphidiploids, wild species, genetic resources, groundnut, Arachis hypogaea..

Received: March 22, 2019; Accepted: July 29, 2019.

\section{Introduction}

Peanut (Arachis hypogaea L.) is used worldwide, mainly for oil or grain consumption. The cultivated area is concentrated in tropical and subtropical regions, and the world production in 2016 was estimated at 42.22 million tons (USDA, 2016). Although yield averages above $4.3 \mathrm{Tg}$ $\mathrm{ha}^{-1}$ are recorded under good management practices, the average yield for most of the peanut-producing countries is only $1.28 \mathrm{Tg} \mathrm{ha}^{-1}$ (USDA, 2016). Disease and pest epidemics are leading factors for suppressed yields, and high levels of resistance to many important biotic stresses are not available in the cultivated genepool (Stalker, 2017).

The genetic variability found in wild Arachis species is much higher than that found in cultivated peanuts. The genus

Send correspondence to Alessandra Pereira Fávero. Embrapa Pecuária Sudeste, Rodovia Washington Luiz, km 234, P.O. Box 339, CEP: 13560-970, São Carlos, SP, Brazil. E-mail: alessandra.favero@embrapa.br.
Arachis has 82 recognized species and is divided into nine taxonomic sections (Krapovickas and Gregory, 1994; Valls and Simpson, 2005; Valls et al., 2013, Santana and Valls, 2015; Valls and Simpson, 2017). Section Arachis is the most important for peanut breeding, and includes 30 species besides A. hypogaea (Krapovickas and Gregory, 1994; Valls and Simpson, 2005). Wild species of this section are diploid (most are $2 \mathrm{n}=2 \mathrm{x}=20$ and only two $2 \mathrm{n}=2 \mathrm{x}=18$ ) except $A$. monticola that is tetraploid like the cultivated peanut (Fernández and Krapovickas, 1994; Lavia, 1998; Peñaloza and Valls, 2005). The cultivated peanut and A. monticola are AABB segmental allotetraploids (Fernández and Krapovickas, 1994; Leal-Bertioli et al., 2015). The diploid species were arranged in six different genomes (A, B, D, F, G, and $\mathrm{K}$ ) according to chromosome morphology, cytogenetic markers, and cross compatibility (Stalker, 1991; Robledo et al., 2009; Robledo and Seijo, 2010; Silvestri et al., 2015).

The difference in ploidy level hinders the direct introgression of genes from wild relatives into the tetraploid pea- 
nut, since hybrids are sterile triploids (Simpson, 2001) but the triploid hybrids can be doubled with colchicine and crossed with $A$. hypogaea, followed by self-fertilization generations to recover the 40-chromosomes conditions (Varman, 2001a,b). The best way to introduce wild alleles into peanut is to produce diploid hybrids and to double the chromosome number with colchicine. The synthetic amphidiploids, which can be compatible at different levels with the cultivated peanut are then crossed and backcrossed with $A$. hypogaea (Simpson and Starr, 2001).

The success of introgression of wild alleles, mainly those related to high resistance to pest and diseases, into peanut is not only restricted by the ploidy level barrier, but also by the effective recombination within interspecific or intergenomic hybrids obtained from crosses among more distant species. Different surveys of resistances in Arachis showed that the most interesting performances were detected in species that are not closely related to peanut (Stalker et al., 2016; Stalker, 2017). Moreover, the amphidiploids derived from species that are genetically closer to peanut, such as $A$. ipaënsis and A. duranensis (Fávero et al., 2005), did not show high resistance against most diseases and pests. By contrast, many of the amphidiploids derived from species that are genetically distant from A. hypogaea presented the highest resistances (Michelotto et al., 2016). Therefore, there is a need to combine the high crossability of some amphidiploids with the high resistance of others in complex hybrids for the effective introgression of desirable traits into peanut.

In this context, the goal of the present study was to develop complex amphidiploids that combine multiple high resistances to diseases and pests and the high crossability with A. hypogaea. For that purpose, the complex hybrids here developed were characterized by means of morphological, molecular, and cytogenetic markers, by pollen viability analyses, and by assays to evaluate resistance to multiple pests and diseases. Many studies show the importance of introgressing Arachis wild genes for pests and diseases resistance, as done in field, laboratory, or greenhouse phenotyping evaluation based on QTL identification (Pande and Rao, 2001; Michelotto et al., 2017; Leal-Bertioli et al., 2015; Zhou et al., 2016). These are the first complex hybrids that include the genome of four distinct species at the same time developed in Arachis, some of them were cross-compatible with peanut, and the derived $\mathrm{F}_{2}$ showed multiple resistances to pests and fungal diseases.

The results here presented showed that the genomes of four distinct wild species could be used simultaneously for the introgression of alleles into cultivated peanuts. With this approach, it was possible to obtain new complex hybrids and peanut introgressed lines with new interesting allelic combinations for peanut breeding programs.

\section{Material and Methods}

\section{Development of complex hybrids}

The Arachis species used for obtaining the amphidiploids are listed in Table 1. All of the A. hypogaea accessions used in the introgression crossing are cultivars that are being used by Brazilian producers.

Crosses were performed at Embrapa Recursos Genéticos e Biotecnologia, Brazil, from January to May 2005 under greenhouse conditions. Emasculations were carried out in late afternoon and pollination was done in the next early morning.

Four previously obtained synthetic amphidiploids (Fávero et al., 2006, 2015) were used in this study (Table 2). Crosses involving four different hybrid combinations were performed: (K $30076 \times$ V 14167) ${ }^{4 x} \times\left(\right.$ K $30006 \times$ V 6325) ${ }^{4 x}$; $(\mathrm{K} 30076 \times \mathrm{V} \mathrm{14167})^{4 \mathrm{x}} \times(\mathrm{V} 6389 x \mathrm{~V} 9401)^{4 \mathrm{x}}$; (V $6389 \mathrm{x} \mathrm{V}$ $9401)^{4 x} \times\left(\right.$ K $30006 \times$ V 6325) ${ }^{4 x}$; (V $6389 \times$ V 9401) ${ }^{4 x} \times(K$ $30006 \times$ G 10017 $)^{4 x}$. After harvest, seeds were dried and stored in cold chambers $\left(10{ }^{\circ} \mathrm{C} / 35 \% \mathrm{RH}\right)$ until the next growing season.

Table 1 - Accessions of Arachis species, collector code, species name, Brazilian accession code (BRA), municipality, state, or country of collection.

\begin{tabular}{|c|c|c|c|c|c|}
\hline Accession* & Species & BRA & Municipality & State/Country** & Genome \\
\hline GKP 10017 & A. cardenasii Krapov. \& W. C.Gregory & 013404 & Roboré & $\mathrm{BOL}$ & AA \\
\hline VNvEv 14167 & A. duranensis Krapov. \& W. C.Gregory & 036200 & Salta & ARG & AA \\
\hline VSGr 6389 & A. gregoryi C.E. Simpson, Krapov. \& Valls & 012696 & Vila Bela da Ssa. Trindade & MT & BB \\
\hline VSGr 6325 & A. helodes Martius ex Krapov. \& Rigoni & 012505 & S. Antonio do Leverger & MT & AA \\
\hline KG 30006 & A. hoehnei Krapov. \& W. C. Gregory & 036226 & Corumbá & MS & $\mathrm{K}$ ? \\
\hline cv. IAC Tatu ST & A. hypogaea L. & 011606 & & BRA & $\mathrm{AABB}$ \\
\hline cv. IAC Runner & A. hypogaea $L$. & 037389 & & BRA & $\mathrm{AABB}$ \\
\hline cv. IAC Caiapó & A. hypogaea $L$. & 037371 & & BRA & $\mathrm{AABB}$ \\
\hline cv. BR 1 & A. hypogaea $L$. & 033383 & & BRA & AABB \\
\hline KGBPScS 30076 & A. ipaënsis Krapov. \& W. C. Gregory & 036234 & Ipá & BOL & BB \\
\hline VPoBi 9401 & A. linearifolia Valls \& C. E.Simpson & 022608 & S. Antonio do Leverger & MT & AA \\
\hline
\end{tabular}

${ }^{*}$ Collector/Institutional abbreviations: B= Banks; Bi= L.B. Bianchetti; Ev=A. Echeverry; G=W.C. Gregory; Gr= A. Gripp; K= A. Krapovickas; Nv= L. Novara; $\mathrm{P}=$ J.R. Pietrarelli; $\mathrm{Po}=$ A. Pott; $\mathrm{S}=$ C.E. Simpson; $\mathrm{Sc}=$ A. Schinini; V=J.F.M. Valls.

**Country or state: $\mathrm{ARG}=$ Argentina; $\mathrm{BOL}=$ Bolívia; $\mathrm{BRA}=\mathrm{Brazil}$; MT= Mato Grosso; MS= Mato Grosso do Sul; $\mathrm{SP}=\mathrm{São} \mathrm{Paulo}$. 
Table 2 - Amphidiploids used in crosses as female and male parents, number of pollinations (NP), number of hybrids obtained (H) and percentage of success in hybrids (PS), percentage of stained pollen (PC), number of $\mathrm{F}_{2}$ seeds obtained $\left(\mathrm{F}_{2}\right)$ and genome.

\begin{tabular}{|c|c|c|c|c|c|c|c|c|c|}
\hline Code & Female parent & & Male parent & NP & $\mathrm{H}$ & PS & $\mathrm{PC}$ & $\mathrm{F}_{2}$ & Genome \\
\hline $\mathrm{HC} 1$ & $(\mathrm{~K} 30076 \times \mathrm{V} 14167)^{4 \mathrm{X}}$ & $\mathrm{x}$ & $(\mathrm{V} 6389 \times \text { V } 9401)^{4 \mathrm{X}}$ & 554 & 19 & 3.43 & $65.13 \mathrm{a}$ & 34 & $\mathrm{~B}_{\mathrm{i}} \mathrm{B}_{\mathrm{g}} \mathrm{A}_{\mathrm{d}} \mathrm{A}_{1}$ \\
\hline $\mathrm{HC} 2$ & $(\mathrm{~K} 30076 \times \mathrm{V} 14167)^{4 \mathrm{X}}$ & $\mathrm{x}$ & $(K 30006 \times$ V 6325) & 296 & 2 & 0.68 & $0.33 \mathrm{c}$ & 1 & $\mathrm{~B}_{\mathrm{i}} \mathrm{A}_{\mathrm{d}} \mathrm{K} ?_{\text {ho }} \mathrm{A}_{\text {he }}$ \\
\hline $\mathrm{HC} 3$ & $(\mathrm{~V} 6389 \times \mathrm{V} 9401)^{4 \mathrm{X}}$ & $\mathrm{x}$ & $(\mathrm{K} 30006 \times \mathrm{V} 6325)^{4 \mathrm{X}}$ & 416 & 4 & 0.96 & $12.50 \mathrm{~b}$ & 0 & $\mathrm{~B}_{\mathrm{g}} \mathrm{A}_{\mathrm{l}} \mathrm{K} ?{ }_{\mathrm{ho}} \mathrm{A}_{\mathrm{he}}$ \\
\hline \multirow[t]{2}{*}{$\mathrm{HC} 4$} & $(\mathrm{~V} 6389 \times \mathrm{V} 9401)^{4 \mathrm{X}}$ & $\mathrm{x}$ & $(\mathrm{K} 30006 \times \mathrm{x} 10017)^{4 \mathrm{X}}$ & 330 & 12 & 3.64 & $7.25 \mathrm{c}$ & 0 & $\mathrm{~B}_{\mathrm{g}} \mathrm{A}_{\mathrm{l}} \mathrm{K} ?_{\mathrm{ho}} \mathrm{A}_{\text {car }}$ \\
\hline & Total & & & 1,596 & 37 & & & & \\
\hline
\end{tabular}

\section{Development of hybrids between complex hybrids and peanut}

The $\mathrm{F}_{1}$ complex hybrids here obtained were crossed with four cultivars of A. hypogaea (A. hypogaea subsp. fastigiata var. fastigiata cv. IAC-Tatu-ST and cv. BR-1, $A$. hypogaea subsp. hypogaea var. hypogaea cv. IAC-Runner 866 and A. hypogaea cv. IAC-Caiapó) (Table 3).

\section{Morphological characterization of the complex hybrids}

Twenty five morphological characteristics were evaluated in the main axis, in lateral branches, and in the flowers of plants kept under greenhouse conditions. Leaflet descriptors were measured in the first expanded leaves, in four replications of each genotype. The morphological descriptors of the main axis (MA) and lateral branch (LB) were: length and width of the apical and basal leaflets, length of petiole and petiolule, length and width of the stipule fused portion, length of the stipule free portion. The morphological descriptors of the flowers (F) were: length and width of the standard and wing, hypanthium length, length of the posterior and inferior lips. The measurements were taken in millimeters with a digital caliper. Data were analyzed using the analysis of variance and Tukey test and based on Principal Component Analysis.

\section{Reproductive characterization of complex hybrids}

Pollen viability estimations were performed by staining with $2 \%$ glycerol-acetic carmine. Four flowers were collected from each plant and 200 pollen grains were counted per flower. Data were analyzed by analysis of variance and Tukey test.

\section{Identification of hybrids using SSR markers}

Progenies and parents were analyzed by microsatellite markers (Table 4) developed for A. hypogaea (Moretzsohn et al., 2013). Total genomic DNA was extracted from young and fresh leaflets of 41 genotypes, including parents and progenies individuals, according to the method of Doyle and Doyle (1990). The amount and quality of the DNA were evaluated by $1 \%$ agarose gel electrophoresis. PCR assays were run with $0.2 \mu \mathrm{DNA}$ Taq polymerase $(5 \mathrm{U} / \mu \mathrm{L}), 0.5 \mu \mathrm{L}$ buffer (with $\mathrm{Mg}$ ), $1.0 \mu \mathrm{L}$ dNTPS ( $2.5 \mathrm{nM}), 1.0 \mu \mathrm{L}$ ultrapure water, $1.2 \mu \mathrm{L}$ BSA $(2.5 \mathrm{mg} / \mathrm{mL}), 0.1 \mu \mathrm{L}$ of each primer $(10$ $\mu \mathrm{m})$ and $2.0 \mu \mathrm{L}$ genomic DNA, in a final volume of $6 \mu \mathrm{L}$. Amplification reactions were performed in an ABI 9700
(Applied Biosystems, Foster City, CA, USA) thermal cycler, under the following conditions: $94^{\circ} \mathrm{C}$ for $5 \mathrm{~min}$, followed by 30 cycles at $94^{\circ} \mathrm{C}$ for $1 \mathrm{~min}, 58^{\circ} \mathrm{C}$ for $1 \mathrm{~min}$ (depending on annealing temperature of the primer), $72^{\circ} \mathrm{C}$ for $1 \mathrm{~min}$, and final extension at $72{ }^{\circ} \mathrm{C}$ for $1 \mathrm{~min}$. The allelic detection of 30 SSR loci was performed in an ABI377 automated sequencer in a multiplex loci system (Table 4). Genetic diversity was analyzed by the PowerMarker V 3.25 and NTSYS programs.

\section{Identification of chromosome complements in the complex hybrids}

The presence of the chromosome complements of each diploid species in the complex hybrid nuclei was investigated by the detection of chromosome markers that included morphology of some chromosome pairs (A9 and SAT chromosomes), heterochromatin amount and distribution, and the number and localization of 18-26 rDNA and 5S rDNA (Robledo et al., 2009; Robledo and Seijo, 2010). For chromosome preparations, root apices pretreated with $2 \mathrm{mM}$

Table 3 - Arachis hypogaea cultivars and complex hybrids used in crosses as female and male parents respectively, number of pollinations (NP), number of hybrids obtained $(\mathrm{H})$ and percentage of success in hybrids (PS), percentage of stained pollen (PC) and number of $\mathrm{F}_{2}$ seeds obtained $\left(\mathrm{F}_{2}\right)$.

\begin{tabular}{lccccccc}
\hline Female parent & & Male parent & $\mathrm{NP}$ & $\mathrm{H}$ & $\mathrm{PS}$ & $\mathrm{PC}$ & $\mathrm{F}_{2}$ \\
\hline IAC Caiapó & $\mathrm{x}$ & $\mathrm{HC} 1$ & 134 & 1 & 0.74 & 65.34 & 8 \\
IAC Runner & $\mathrm{x}$ & $\mathrm{HC} 1$ & 87 & 1 & 1.15 & 80.69 & 18 \\
IAC Tatu ST & $\mathrm{x}$ & $\mathrm{HC} 1$ & 146 & 0 & 0 & $\mathrm{Na}$ & 0 \\
BR 1 & $\mathrm{x}$ & $\mathrm{HC1}$ & 184 & 0 & 0 & $\mathrm{Na}$ & 0 \\
IAC Caiapó & $\mathrm{x}$ & $\mathrm{HC} 2$ & 20 & 0 & 0 & $\mathrm{Na}$ & 0 \\
IAC Runner & $\mathrm{x}$ & $\mathrm{HC} 2$ & 38 & 2 & 5.26 & 89.42 & 44 \\
IAC Tatu ST & $\mathrm{x}$ & $\mathrm{HC} 2$ & 53 & 1 & 1.89 & 76.35 & 87 \\
BR 1 & $\mathrm{x}$ & $\mathrm{HC} 2$ & 48 & 1 & 2.08 & $\mathrm{Ne}$ & 0 \\
IAC Caiapó & $\mathrm{x}$ & $\mathrm{HC} 3$ & 74 & 0 & 0 & $\mathrm{Na}$ & 0 \\
IAC Runner & $\mathrm{x}$ & $\mathrm{HC} 3$ & 52 & 0 & 0 & $\mathrm{Na}$ & 0 \\
IAC Tatu ST & $\mathrm{x}$ & $\mathrm{HC} 3$ & 157 & 0 & 0 & $\mathrm{Na}$ & 0 \\
BR 1 & $\mathrm{x}$ & $\mathrm{HC} 3$ & 91 & 0 & 0 & $\mathrm{Na}$ & 0 \\
IAC Caiapó & $\mathrm{x}$ & $\mathrm{HC} 4$ & 57 & 0 & 0 & $\mathrm{Na}$ & 0 \\
IAC Runner & $\mathrm{x}$ & $\mathrm{HC} 4$ & 36 & 0 & 0 & $\mathrm{Na}$ & 0 \\
IAC Tatu ST & $\mathrm{x}$ & $\mathrm{HC} 4$ & 194 & 0 & 0 & $\mathrm{Na}$ & 0 \\
BR 1 & $\mathrm{x}$ & $\mathrm{HC} 4$ & 117 & 0 & 0 & $\mathrm{Na}$ & 0 \\
Total & & & 1,488 & 6 & & & \\
\hline
\end{tabular}

$\mathrm{Ne}=$ non-evaluated

$\mathrm{Na}=$ not applicable 
Table 4 - Multiplex systems, labeled primers and their respective fluorescence, base pair size, amplification temperature, and the products that were amplified and analyzed.

\begin{tabular}{|c|c|c|c|c|c|}
\hline Multiplex & Primer & Fluorescence & $\begin{array}{l}\text { Size } \\
\text { (bp) }\end{array}$ & $\begin{array}{l}\text { Tempera- } \\
\text { ture }\left({ }^{\circ} \mathrm{C}\right)\end{array}$ & Analyzed \\
\hline \multirow[t]{3}{*}{1} & TC3E02 & Blue & $270-310$ & 58 & $\mathrm{X}$ \\
\hline & AC2H11 & Green & $230-270$ & 58 & $\mathrm{X}$ \\
\hline & TC7G10 & Blue & $110-142$ & 58 & $\mathrm{X}$ \\
\hline \multirow[t]{3}{*}{2} & TC7H11 & Blue & $340-360$ & 58 & $\mathrm{X}$ \\
\hline & $\mathrm{RN} 2 \mathrm{C} 06$ & Green & $190-220$ & 58 & $\mathrm{X}$ \\
\hline & TC6E01 & Blue & $154-186$ & 58 & $\mathrm{X}$ \\
\hline \multirow[t]{4}{*}{3} & TC7A02 & Blue & $308-320$ & 58 & $\mathrm{X}$ \\
\hline & GI-338 & Green & $240-270$ & 58 & $\mathrm{X}$ \\
\hline & TC4F12 & Blue & $220-232$ & 58 & $\mathrm{X}$ \\
\hline & GI-832 & Green & $200-210$ & 56 & $\mathrm{X}$ \\
\hline \multirow[t]{3}{*}{4} & TC11A02 & Green & $284-292$ & 58 & $\mathrm{X}$ \\
\hline & TC6H03 & Blue & $210-228$ & 58 & $\mathrm{X}$ \\
\hline & RN22G07 & Green & $180-210$ & 58 & $\mathrm{X}$ \\
\hline \multirow[t]{3}{*}{5} & TC9F10 & Green & $286-320$ & 56 & $\mathrm{X}$ \\
\hline & TC1D02 & Blue & $242-278$ & 56 & $\mathrm{X}$ \\
\hline & GI-342 & Green & $210-240$ & 58 & $\mathrm{X}$ \\
\hline \multirow[t]{3}{*}{6} & RNO-681 & Green & $310-350$ & 54 & \\
\hline & TC7E04 & Blue & $290-300$ & 56 & $\mathrm{X}$ \\
\hline & TC9F04 & Green & $122-142$ & 54 & \\
\hline \multirow[t]{3}{*}{7} & $\mathrm{AC} 2 \mathrm{~B} 03$ & Green & $296-308$ & 54 & $\mathrm{X}$ \\
\hline & ТC2B09 & Blue & $190-200$ & 52 & $X$ \\
\hline & RI1F06 & Green & $312-372$ & 56 & $\mathrm{X}$ \\
\hline \multirow[t]{2}{*}{8} & GI-1107 & Green & $360-384$ & 52 & $X$ \\
\hline & TC1A02 & Blue & $240-276$ & 54 & $\mathrm{X}$ \\
\hline \multirow[t]{3}{*}{9} & TC3H02 & Blue & $280-300$ & 54 & $\mathrm{X}$ \\
\hline & TC11A04 & Green & $172-204$ & 52 & $\mathrm{X}$ \\
\hline & TC6G09 & Blue & $132-146$ & 50 & $\mathrm{X}$ \\
\hline \multirow[t]{2}{*}{10} & TC2A02 & Blue & $194-212$ & 48 & $\mathrm{X}$ \\
\hline & RNO-615 & Green & $390-400$ & 56 & \\
\hline \multirow[t]{4}{*}{11} & TC1E01 & Blue & $154-248$ & 48 & $X$ \\
\hline & ТC9C12 & Green & $256-300$ & 54 & \\
\hline & TC7C06 & Blue & $148-176$ & 52 & $\mathrm{X}$ \\
\hline & TC11H06 & Green & $190-214$ & 52 & $\mathrm{X}$ \\
\hline \multirow[t]{4}{*}{12} & TC1A01 & Blue & $202-222$ & 54 & \\
\hline & TC2D06 & Blue & $196-224$ & 48 & \\
\hline & TC3E05 & Blue & $358-370$ & 48 & \\
\hline & RN8C09 & Green & $260-290$ & 56 & $\mathrm{X}$ \\
\hline
\end{tabular}

8-hydroxyquinoline for $3 \mathrm{~h}$ and fixed in 3:1 absolute ethanol:glacial acetic acid (Fernández and Krapovickas, 1994) were digested in $1 \%(\mathrm{w} / \mathrm{v})$ cellulose (Onozuka) plus $10 \%$ (v/v) pectinase (Sigma) solution in 0.01 at $37{ }^{\circ} \mathrm{C}$ for $2 \mathrm{~h}$. The meristematic cells were squashed in $45 \%$ acetic acid.

The $18 \mathrm{~S}-26 \mathrm{~S}$ and $5 \mathrm{~S}$ rDNA loci were localized using probes isolated from genomic DNA of A. hypogaea (Robledo and Seijo, 2008). Pretreatment of preparations, chromosome and probe denaturation, conditions for the in situ hybridization (hybridization mixes contained DNA probes at a concentration of $2.5-3.5 \mathrm{ng} / \mathrm{L}$, with a stringency to allow sequences with $80-85 \%$ identity to remain hybridized), posthybridization washing, blocking and indirect detection with fluorochrome-conjugated antibodies were performed according to Moscone et al. (1996) and Seijo et al. (2004). Chromosomes were analyzed and photographed with an epifluorescence microscope equipped with a digital camera system. Red, green and blue images were captured in black and white using appropriate filters for TRITC, FITC, and DAPI excitation, respectively. Digital images were combined and then processed for color balance, brightness, and contrast for uniformity across the image.

\section{Phytopathological and entomological characterization of complex hybrids under laboratory conditions}

Bioassays were performed using detached leaves (Moraes and Salgado, 1982) under controlled laboratory conditions to verify resistance to rust (Puccinia arachidis Speg.), fall armyworm (Spodoptera frugiperda J.E. Smith), and velvetbean caterpillar (Anticarsia gemmatalis Hübner). The four complex hybrids (three in the velvetbean caterpillar assay) and the IAC Tatu ST peanut cultivar as susceptible control were included in the assays.

\section{Characterization of complex hybrids for resistance to rust (Puccinia arachidis Speg.)}

Four leaves of each genotype were evaluated after 23 days of experiment. The bioassay was carried out in Petri dishes filled with a cotton layer and one blotter paper according to Moraes and Salgado (1982). The inoculation was performed using a spore solution at 100,000 spores of rust $\mathrm{mL}^{-1}$. The number of pustules per leaf area $\left(\mathrm{cm}^{2}\right)$ was counted. Data were analyzed using the $t$-test.

\section{Characterization of complex hybrids for resistance to velvetbean caterpillar (Anticarsia gemmatalis Hübner)}

One leaf of each genotype and two caterpillars (firstor third-instar) were kept in each sealed Petri dish filled with a cotton layer and one blotter paper (Moraes and Salgado, 1982). Four replications per genotype using first-instar caterpillars were evaluated seven days after assembling the trial. The third-instar caterpillars were evaluated after four days. Data of damaged leaf area were analyzed by the $t$-test.

\section{Characterization of complex hybrids for the resistance to fall armyworm (Spodoptera frugiperda J.E. Smith)}

One leaf of each genotype and two first-instar caterpillars were kept in a sealed Petri dish filled with a cotton layer and one blotter paper. Four replications of each genotype were analyzed after a five-day experiment. The damaged leaf area was evaluated by a 1-4 damage scale (1-resistant, 2-moderate resistant, 3-moderate susceptible, 4-susceptible). Data of damaged leaf area were analyzed by the $t$-test. 


\section{Phytopathological characterization under field conditions}

\section{Characterization of the complex hybrids}

Field trials were carried out at APTA Polo Centro Norte in Pindorama, São Paulo State, Brazil (21 ${ }^{\circ} 13^{\prime} \mathrm{S}$ and $\left.48^{\circ} 55^{\prime} \mathrm{W}\right)$, where inoculum pressure for peanut phytopathogenic fungi is considered high. Three complex hybrids were evaluated: HC1 ((K 30076 x V14167) ${ }^{4 x}$ x (K $30006 x$ V 6325) $)^{4 x}$; HC3 (V 6389 x V 9401) ${ }^{4 x}$ x (K 30006 x V 6325) $)^{4 x}$; HC4 (V 6389 x V 9401) ${ }^{4 x} \times\left(\right.$ K 30006 x G 10017) $\left.{ }^{4 x}\right)$ and the peanut cultivar IAC Caiapó. For the Sphaceloma arachidis assay, the peanut cultivar BR-1 was also included as control.

The resistance trial was performed in four randomized blocks, with five plants per 1.5 meter rows with 0.90 spacing between rows. Seeds and seedlings were planted in pots and transplanted to the field when rooted. The evaluation was performed at 90 days. Two types of evaluation were performed: 1) using a 1-9 score scale that identifies defoliation index and damaged leaf area (Subrahmanyam et al., 1982), and 2) disease severity in the most attacked leaf of the plant. The most damaged leaves of each plant and each genotype were collected for evaluation. The evaluated diseases were late leaf spot (Cercosporidium personatum Berk and M.A. Curtis), rust, early leaf spot (Cercospora arachidicola Hori), and scab (Sphaceloma arachidis Bitanic and Jenkins). Leaves were scanned and evaluated by the analysis of the damaged area using the Image Tool ${ }^{\circledR}$ Free Software. Statistical analyses were performed using the $t$-test.

\section{Characterization of the $F_{2}$ progenies for foliar fungal diseases}

The field assay was performed including $\mathrm{F}_{2}$ progenies, amphidiploids, complex hybrids, and $A$. hypogaea cultivars. Seeds were treated with Plantacol ${ }^{\circledR}$ fungicide ( $10 \mathrm{~g}$ per 100 $\mathrm{kg}$ seeds) and put to germinate into blotter paper, conditioned at $26\left(3{ }^{\circ} \mathrm{C}, 70(10 \% \mathrm{RH}\right.$, and photoperiod of 12 hours. Seedlings were put in plastic cups $(200 \mathrm{ml})$ with soil and manure (3:1) and kept in greenhouse conditions. Fifteen days after emergence, the plants were put in field. Plants of the $F_{1}$ were planted by branches. Genotypes were placed as random blocks with four replications, with five plants per plot ( $1 \mathrm{~m}$ between plants, $1.5 \mathrm{~m}$ between plots and $1.8 \mathrm{~m}$ between rows). All plots were fertilized with 8-28-16 NPK formula as $250 \mathrm{~kg} / \mathrm{ha}$ dosis. The insecticide tiametoxam + lambda-cialotrina (Engeo ${ }^{\mathrm{TM}}$ Pleno, Syngenta) was sprayed every 15 days at $0,15 \mathrm{~L} /$ ha dosis to thrips (Enneothrips flavens (Moulton, 1941) (Thysanoptera: Thripidae)) and rednecked armyworm (Stegasta bosquella (Chambers, 1875) (Lepidoptera: Gelechidae) control. Pre-emergent trifluraline herbicide $(2.5 \mathrm{~L} / \mathrm{ha})$ was used for weed control. Manual weeding control were done as necessary.

Foliar disease resistance evaluations were performed at $65,80,95$ and 125 days after the transplant to the field. A 1 to 9 diagrammatic scale was used, where 1 meant no symptoms and 9 meant high disease infestation and high defoliation (Subrahmanyam et al., 1982). The severity was evaluated by the use of the area under disease progress curve
(AUDPC) based on the formula AUDPC $=\Sigma[((\mathrm{y} 1+$ $\left.\mathrm{y} 2) / 2)^{*}(\mathrm{t} 2-\mathrm{t} 1)\right]$, where $\mathrm{y} 1$ and $\mathrm{y} 2$ are two consecutive evaluations performed on times $\mathrm{t} 1$ and $\mathrm{t} 2$, respectively. A principal component analysis was performed based on AUDPC and the detached leaves data.

\section{Results}

\section{Development and reproductive behavior of complex hybrids}

A total of 1,596 pollinations were performed, resulting in hybrids from all the combinations, with a total of 37 individuals considered as complex hybrids (Table 2). The hybridization rate ranged from 0.68 to $3.64 \%$. Hybrids were conserved in pots under greenhouse conditions. The percentage of stained pollen grains of the complex hybrids ranged from 0.33 to $65.13 \%$ (Table 2).

Only two combinations produced fertile hybrids: $\mathrm{HC} 1$ (A. ipaënsis $\mathrm{x} A$. duranensis $)^{4 \mathrm{x}} \mathrm{x}(A$. gregoryi $\mathrm{x}$ A. lineari-

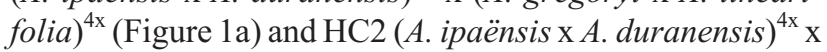

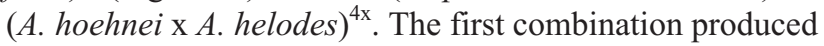
$34 \mathrm{~F}_{2}$ seeds, while the second one generated only one $\mathrm{F}_{2}$ seed (Table 2). The combinations HC3 (A. gregoryi $\mathrm{x}$ A. linearifolia $^{4 \mathrm{x}} \mathrm{x}(\text { A. hoehnei } \mathrm{x} \text { A. helodes })^{4 \mathrm{x}}$ and $\mathrm{HC} 4$ (A. gregoryi $\mathrm{x}$ A. linearifolia $)^{4 \mathrm{x}} \times(A \text {. hoehnei } \mathrm{x} A \text {. cardenasii })^{4 \mathrm{x}}$ generated $\mathrm{F}_{1}$ hybrids with higher pollen viability than $\mathrm{HC} 2$, but did not produce $\mathrm{F}_{2}$ seeds.

\section{Morphological characterization of the complex hybrids}

The morphological characterization showed significant differences in nine out of the 25 descriptors analyzed in the complex hybrids (Table 5). These descriptors were: length and width of the basal leaflet, and width of the apical leaflet in the main axis (MA); length of the apical leaflet and length of the stipule adnate portion in the lateral branch (LB); standard and hypanthium length, and length and width of the wing in flowers (F). The coefficients of variation among descriptors ranged from 5.9 (wing length) to $41.13 \%$ (length of the stipule adnate portion on the main axis).

Eigenvalues showed that the two first components explain $82.23 \%$ of the total morphological variation. The eight main descriptors that discriminated the complex hybrids in the principal component analysis were (in order of importance): apical leaflet length, basal leaflet length, apical leaflet width, and basal leaflet width of the main axis; apical leaflet width, length of the stipule free portion, and basal leaflet length of lateral branches, and finally, length of the stipule free portion on the main axis. The dispersion observed in Figure 2 evidenced a clear morphological distinctness among the complex hybrids, being $\mathrm{HC} 1$ and $\mathrm{HC} 3$ the most similar.

\section{Mitotic chromosomes of $F_{1}$ complex hybrids}

All the complex amphidiploid hybrids analyzed presented $2 \mathrm{n}=4 x=40$. The cytological markers evidenced that the amphidiploids are composed of one complete chromo- 


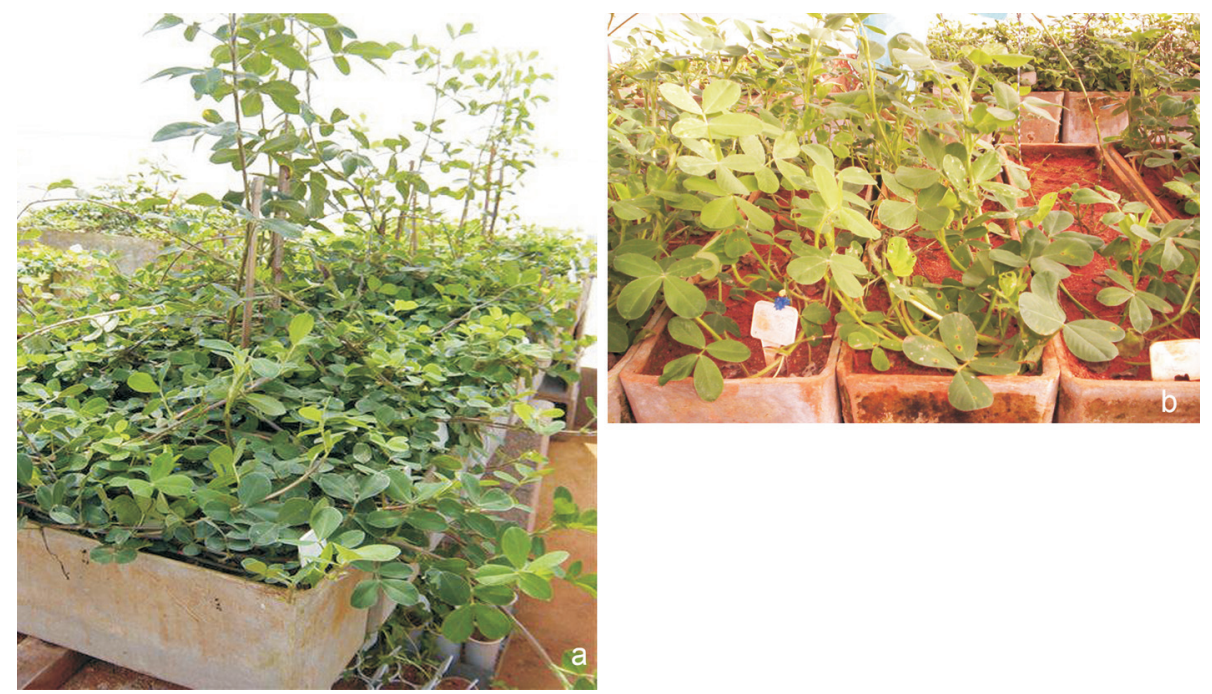

Figure 1 - Complex Arachis hybrds (a) Complex hybrid (A. ipaënsis x A. duranensis $)^{4 \mathrm{x}} \mathrm{x}$ (A. gregoryi x A. linearifolia $)^{4 \mathrm{x}}$, (b) cv. IAC Runner x (A. ipaënsis x A. duranensis $)^{4 \mathrm{x}} \mathrm{x}(\text { A. gregoryi } \mathrm{x} \text { A. linearifolia })^{4 \mathrm{x}}$.

Table 5 - Morphological descriptors of complex hybrids.

\begin{tabular}{|c|c|c|c|c|c|}
\hline Descriptor & $\mathrm{HC} 1$ & $\mathrm{HC} 2$ & $\mathrm{HC} 3$ & $\mathrm{HC} 4$ & $\mathrm{CV} \%$ \\
\hline Apical leaflet length MA* & $63.39 \mathrm{a}$ & $62.12 \mathrm{a}$ & $67.55 \mathrm{a}$ & $48.56 \mathrm{a}$ & 15.51 \\
\hline Basal leaflet length MA & $57.20 \mathrm{ab}$ & $53.68 \mathrm{ab}$ & $61.93 \mathrm{a}$ & $45.18 \mathrm{~b}$ & 13.94 \\
\hline Apical leaflet width MA & $31.29 \mathrm{a}$ & $26.19 \mathrm{ab}$ & $24.66 \mathrm{ab}$ & $20.64 \mathrm{~b}$ & 16.08 \\
\hline Basal leaflet width MA & $24.59 \mathrm{a}$ & $20.16 a b$ & $19.40 \mathrm{ab}$ & $16.52 \mathrm{~b}$ & 17.49 \\
\hline Petiolule length MA & $19.21 \mathrm{a}$ & $17.45 \mathrm{a}$ & $20.63 \mathrm{a}$ & $15.48 \mathrm{a}$ & 17.41 \\
\hline Petiole length MA & $53.37 \mathrm{a}$ & $51.98 \mathrm{a}$ & $59.11 \mathrm{a}$ & $53.82 \mathrm{a}$ & 17.25 \\
\hline Length of the stipule adnate part MA & $6.02 \mathrm{a}$ & $11.39 \mathrm{a}$ & $5.85 \mathrm{a}$ & $7.43 \mathrm{a}$ & 41.13 \\
\hline Length of the stipule free part MA & $30.50 \mathrm{a}$ & $27.39 \mathrm{a}$ & $31.72 \mathrm{a}$ & $26.23 \mathrm{a}$ & 11.89 \\
\hline Width of the stipule adnate part MA & $3.63 \mathrm{a}$ & $3.61 \mathrm{a}$ & $3.54 \mathrm{a}$ & $3.83 \mathrm{a}$ & 21.51 \\
\hline Apical leaflet length LB & $34.01 \mathrm{ab}$ & $45.69 \mathrm{a}$ & $33.02 \mathrm{ab}$ & $30.34 \mathrm{~b}$ & 20.15 \\
\hline Basal leaflet length LB & $31.34 \mathrm{a}$ & $36.81 \mathrm{a}$ & 28.63 a & $27.79 \mathrm{a}$ & 23.44 \\
\hline Apical leaflet width LB & $25.17 \mathrm{a}$ & $26.48 \mathrm{a}$ & $19.90 \mathrm{a}$ & $18.10 \mathrm{a}$ & 20.94 \\
\hline Basal leaflet width LB & $19.60 \mathrm{a}$ & $20.75 \mathrm{a}$ & $15.46 \mathrm{a}$ & $15.26 \mathrm{a}$ & 22.76 \\
\hline Petiolule length LB & $22.73 \mathrm{a}$ & $28.22 \mathrm{a}$ & $18.22 \mathrm{a}$ & $23.89 \mathrm{a}$ & 30.26 \\
\hline Petiole length LB & $12.55 \mathrm{a}$ & $13.16 \mathrm{a}$ & $12.67 \mathrm{a}$ & $10.51 \mathrm{a}$ & 17.47 \\
\hline Length of the stipule adnate part LB & $5.91 \mathrm{ab}$ & $7.74 \mathrm{a}$ & $4.11 \mathrm{~b}$ & $4.37 \mathrm{~b}$ & 17.04 \\
\hline Length of the stipule free part LB & $20.18 \mathrm{a}$ & $21.41 \mathrm{a}$ & $18.42 \mathrm{a}$ & $15.61 \mathrm{a}$ & 15.58 \\
\hline Width of the stipule adnate part LB & $4.32 \mathrm{a}$ & $3.70 \mathrm{a}$ & $3.74 \mathrm{a}$ & $3.97 \mathrm{a}$ & 17.14 \\
\hline Standard length & $10.07 \mathrm{~b}$ & $13.20 \mathrm{a}$ & $12.20 \mathrm{a}$ & $12.26 \mathrm{a}$ & 5.97 \\
\hline Standard width & $6.54 \mathrm{a}$ & $7.75 \mathrm{a}$ & $6.83 \mathrm{a}$ & $6.77 \mathrm{a}$ & 8.97 \\
\hline Wing length & $7.44 \mathrm{~b}$ & $8.34 \mathrm{ab}$ & $9.08 \mathrm{a}$ & $9.08 \mathrm{a}$ & 5.90 \\
\hline Width of the wing width & $4.91 \mathrm{~b}$ & $6.38 \mathrm{ab}$ & $5.82 \mathrm{ab}$ & $6.43 \mathrm{a}$ & 11.54 \\
\hline Inferior lip length & $6.99 \mathrm{a}$ & $6.69 \mathrm{a}$ & $8.88 \mathrm{a}$ & $9.14 \mathrm{a}$ & 13.82 \\
\hline Posterior lip length & $5.57 \mathrm{a}$ & $5.74 \mathrm{a}$ & $5.59 \mathrm{a}$ & $6.51 \mathrm{a}$ & 15.52 \\
\hline Hypanthium length & $13.40 \mathrm{~b}$ & $28.50 \mathrm{a}$ & $29.76 \mathrm{a}$ & $34.44 \mathrm{a}$ & 22.29 \\
\hline
\end{tabular}

$*$ in $\mathrm{mm} . \mathrm{MA}=$ Main axis, $\mathrm{LB}=$ Lateral branch. $\mathrm{CV} \%=$ coefficient of variation (in percentage)

Data with the same letters were considered similar at $5 \%$ probability

some complement of each of the diploid progenitors used in the initial crosses. The genome constitutions of the amphidiploids were as expected (Table 6); while HC2 (Figure 3b), HC3 (Figure 3c), and HC4 (Figure 3d) were AA K?hoB. The complements of the B genome (A. ipaënsis and A. gregoryi) were clearly detected by the absence of conspicuous heterochromatic centromeric bands. The complements of the A genome (A. cardenasii, A. duranensis, A. linearifolia) were 


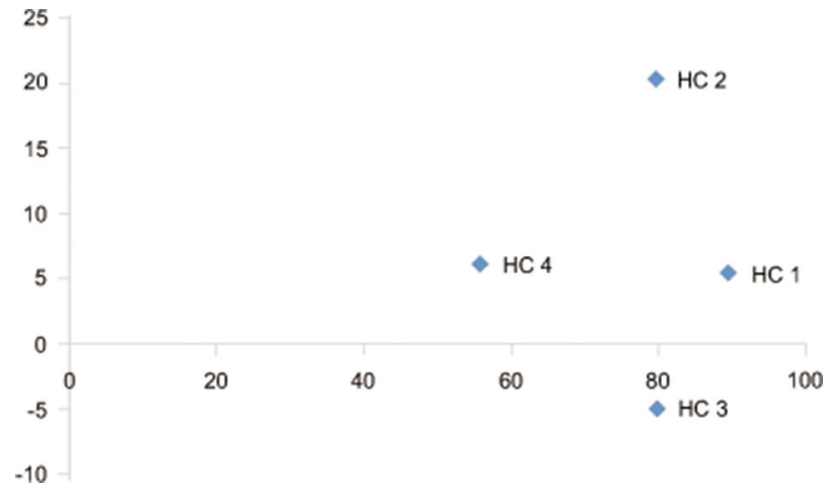

Figure 2 - Principal Component Analysis based on morphological data of the complex hybrids. The plot represents the spatial distribution of the hybrids according to the first two axes.
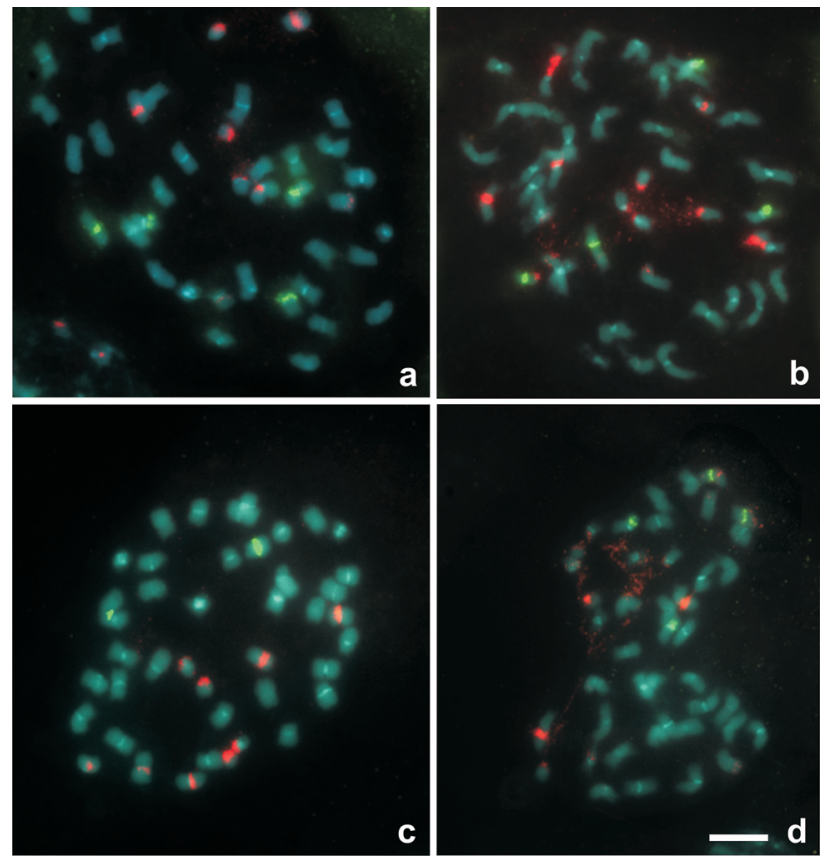

Figure 3 - Representative somatic metaphases of the four complex hybrids after double fluorescent in situ hybridization (FISH), showing yellow-green FITC signals from the 5S rDNA probe, and red TRITC signals from the 18S-26S rDNA probe. DAPI counterstaining (light blue) was used to highlight the heterochromatic bands and to stain euchromatin. (a) $\mathrm{HC}$; (b) $\mathrm{HC} 2$; (c) $\mathrm{HC} 3$; (d) HC4. In all the tetraploids, the 18S-26S loci with extended secondary constrictions were those of the A10 pair and more rarely those of the $\mathrm{A} 2$ pair or those of the $\mathrm{B} 10$ pair. Scale $\mathrm{bar}=5 \mu \mathrm{m}$. distinguished by the presence of conspicuous heterochromatic centromeric bands in all their chromosomes and by the A9 pair, which is the smallest chromosome with the largest heterochromatic band (around $40 \%$ of the chromosome length) and diffuse chromosome arms. The complement of $A$. hoehnei was also detected by the presence of heterochromatic bands in all their chromosomes, and the presence of a small chromosome but structurally different from the A9 (without diffuse arms). The patterns of 18-26S and 5S rDNA of $A$. ipaënsis and A. gregoryi were conserved in the complex hybrids. Most of the chromosome markers here analyzed revealed similar patterns in all the of A genome diploid species, thus the identification of species-specific chromosomes in the amphidiploids was not possible or tentative. However, the number of rDNA loci and A9 chromosomes and the pattern of heterochromatin observed was as expected in $\mathrm{HC} 1, \mathrm{HC} 2$ and HC4. Only in HC3 the number of observed 5S rDNA was two instead of the four expected from their parental species.

The analysis of secondary constrictions and patters of 18-26S rDNA revealed the occurrence of amphiplasty. In most cases, the extended nucleolar organizing regions observed in late prometaphase or metaphases were in chromosomes that belong to the A genome.

\section{Obtaining hybrids between complex hybrids and cultivated peanuts}

After 1,488 hybridizations performed in 16 different cross combinations, only six hybrid individuals were obtained (Table 3): two from crosses between cultivars of $A$. hypogaea subsp. hypogaea var. hypogaea (IAC Caiapó and $\mathrm{IAC}$ Runner) and $\mathrm{HC} 1$ (A. ipaënsis $\mathrm{x} A$. duranensis $)^{4 \mathrm{x}} \mathrm{x}(A$. gregoryi $\mathrm{x} A$. linearifolia $)^{4 \mathrm{x}}$ (Figure $1 \mathrm{~b}$ ), and four hybrids between three cultivars of $A$. hypogaea (IAC Runner, IAC Tatu $\mathrm{ST}$ and BR 1) and the complex hybrid HC2 (A. ipaënsis $\mathrm{x} A$. duranensis $^{4 \mathrm{x}} \times(A \text {. hoehnei } \mathrm{x} \text { A. helodes })^{4 \mathrm{x}}$.

The percentage of stained pollen grains of $\mathrm{F}_{1}$ hybrids between the complex hybrids and $A$. hypogaea was relatively high and varied from 65.34 to 89.42 (Table 3). Notably, the percentages of stained pollen grains were higher with the HC2 hybrid in which the genome formula was BK?hoAA than with $\mathrm{HC} 1$, which had the genome formula BBAA. The $\mathrm{F}_{1}$ hybrids obtained from the crosses of cv. IAC Caiapó and IAC Runner 886 with $\mathrm{HC} 1$ produced 8 and $18 \mathrm{~F}_{2}$ seeds, respectively. The $\mathrm{F}_{1}$ hybrids generated from the crosses of cv. IAC Runner 886 and IAC Tatu ST with HC2 produced 44 and $87 \mathrm{~F}_{2}$ seeds, respectively.

Table 6 - Chromosome markers observed in the complex hybrids. Expected markers were summarized according to published data.

\begin{tabular}{|c|c|c|c|c|c|c|}
\hline \multirow[t]{2}{*}{ Hybrid } & \multicolumn{2}{|l|}{$45 \mathrm{~S}$ rDNA } & \multicolumn{2}{|l|}{$5 \mathrm{~S}$} & \multicolumn{2}{|c|}{ A9 $+\operatorname{small} A$. hoehnei } \\
\hline & Expected & Observed & Expected & Observed & Expected & Observed \\
\hline $\mathrm{HC} 1$ & $8(3$ ipa +2 greg $)+(2$ dur +1 lin $)$ & $8(5 B+3 A)$ & $4(1$ ipa +1 greg $)+(1$ dur+1lin $)$ & 4 & 2 & 2 \\
\hline $\mathrm{HC} 2$ & 10 (3ipa) $+(2$ dur +2 hoeh +3 hel $)$ & $10(3 \mathrm{~B}+4-5 \mathrm{~A}+2 \mathrm{ho})$ & 4 (1ipa) $+(1$ dur +1 hoeh +1 hel $)$ & 4 & $2+1$ & $2+1$ \\
\hline $\mathrm{HC} 3$ & $8(2$ greg $)+(1$ lin +2 hoeh +3 hel $)$ & $8(2 \mathrm{~B}+3 \mathrm{~A}+2 \mathrm{ho})$ & $4($ greg $)+(1$ lin +1 hoeh +1 hel $)$ & $2(4)$ & $2+1$ & $2+1$ \\
\hline $\mathrm{HC} 4$ & $9(2$ greg $)+(1$ lin +2 hoeh +4 card $)$ & $9(2-3 \mathrm{~B}+5 \mathrm{~A}+2 \mathrm{ho})$ & $4(1$ Greg $)+(1$ lin +1 hoeh +1 card $)$ & 4 & $2+1$ & $2+1$ \\
\hline
\end{tabular}


Identification of hybrids via molecular characterization

Molecular markers were informative for the identification of hybrid individuals (Table 7). Plants considered hybrid on morphological and reproductive analysis presented the expected bands inherited from their respective male parents (in gray). The markers TC7A02 and TC6E0 were the most informative for the hybrid identification. Although the AC2H11 and RN2C06 markers were less informative, they also contributed to corroborate the results of the two former microsatellites.

\section{Phytopathological and entomological characterization of complex hybrids under laboratory conditions}

All the complex hybrids showed significant higher resistance to rust, fall armyworm, and velvetbean caterpillar when compared to the control IAC Tatu ST (Table 8). The resistance to caterpillars showed a similar pattern in the two instars analyzed.

Besides the lower degree of lesions observed in the hybrids compared with the $A$. hypogaea cultivar analyzed (Figure 4), lesser growth of fall armyworm was also observed when they were fed on complex hybrids leaves.

\section{Phytopathological characterization under field conditions}

\section{Characterization of the complex hybrids}

The main disease observed in the field evaluations was the late leaf spot, although lesions caused by other pathogens were also observed in different degrees. Table 9 shows that all the complex hybrids analyzed proved to be more resistant than the cultivar IAC Caiapó to late leaf spot, rust ,and early leaf spot. Complex hybrids were also more resistant to scab than cultivar BR 1.

\section{Characterization of the $F_{2}$ progenies}

A biplot graph (Figure 5) was performed based on the AUDPC and the detached leaves data from parents, averages of $\mathrm{F}_{2}$ progenies and the outstand plant of each progeny (selected plant - sp). All $\mathrm{F}_{2}$ hybrids were located closer to the wild parents than to $A$. hypogaea cultivars. All peanut cultivars, even the most resistant one (IAC 503), were more susceptible than any wild parents, the $\mathrm{F}_{1}$ and $\mathrm{F}_{2}$ hybrid progenies.

\section{Discussion}

It is known that the amphidiploid (A. ipaënsis x A. duranensis $)^{4 \mathrm{x}}$ shows the best cross compatibility with peanut, but it is not the most resistant to diseases and pests (Michelotto et al., 2015, 2016). This is because A. ipaënsis and $A$. duranensis are the ancestors of cultivated peanut (Kochkert et al., 1996; Seijo et al., 2004; Fávero et al., 2006; Bertioli et al., 2016). The high crossability of this AABB wild amphidiploid is highly relevant, since it can be used as a bridge for introgression of resistance genes located in other wild species that produced non-crossing amphidiploids, or which generate sterile $F_{1}$ population with the cultivated peanut. Here, we demonstrated that the introgression of genes from non directly related diploid species into peanut is feasible by using a bridge AABB amphidiploid.

The hybridization assays between amphidiploids demonstrated that not all the combinations are equally compatible, since two of the four $\mathrm{F}_{1}$ complex amphidiploids produced viable $\mathrm{F}_{2}$ seeds. Moreover, it is worthy of note that the $\mathrm{F}_{2}$ of $\mathrm{HC} 1$ was more fertile (with $34 \mathrm{~F}_{2}$ seeds) than that of $\mathrm{HC} 2$ (with only one $\mathrm{F}_{2}$ seed). This difference between $\mathrm{HC} 1$ and $\mathrm{HC} 2$ is probably related to the genome constitution of the male amphidiploid. In $\mathrm{HC} 1, A$. gregory and A. linearifolia belong to the $\mathrm{A}$ and $\mathrm{B}$ genomes, respectively, and therefore a high chromosome homeologous pairing is expected in the $\mathrm{F}_{1}$ meiosis with $\mathrm{A}$. ipaënsis (B genome) and $A$. duranensis (A genome). In $\mathrm{HC} 2$, while $A$. helodes is a well-known A genome species, A. hoehnei does not belong to the $\mathrm{B}$ genome, being probably of the $\mathrm{K}$ genome (Custodio et al., 2013). Even though it was demonstrated that the $B$ and $\mathrm{K}$ genomes have partial homeology (Leal-Bertioli et al., 2015), it is expected that meiosis was not as regular in the case of AABB complex hybrids as discussed above. The difference in meiotic behavior discussed here is clearly reflected in the pollen stainability of the $\mathrm{F}_{1}$ of these hybrids, ( 65.13 in the $\mathrm{F}_{1}$ of $\mathrm{HC} 1$ and $0.33 \%$ in that of $\mathrm{HC} 2$ ). The sterility of $\mathrm{F}_{1}$ complex hybrids $\mathrm{HC} 3$ and $\mathrm{HC} 4$ demonstrated that even among species within the same genome there are significant different reproductive isolation barriers preventing production of viable $\mathrm{F}_{2}$.

Our results also showed a differential reproductive behavior of $\mathrm{HC1}\left[(\text { A. ipaënsis } \mathrm{x} \text { A. duranensis })^{4 \mathrm{x}} \mathrm{x}(\right.$ A. gregoryi $\mathrm{x}$ A. linearifolia $\left.)^{4 \mathrm{x}}\right]$ and $\mathrm{HC} 2\left[(\text { A. ipaënsis } \mathrm{x} \text { A. duranensis })^{4 \mathrm{x}}\right.$ $\left.\mathrm{x}(A \text {. hoehnei } \mathrm{x} A \text {. helodes })^{4 \mathrm{x}}\right]$ with peanut. Interesting is the fact that in both cases the female amphidiploid came from the hybridization of the diploid progenitors of peanut. It is worthy of note that the $\mathrm{F}_{1}$ hybrids obtained showed more than $60 \%$ of stained pollen and produced fertile $\mathrm{F}_{2}$, which indirectly evidenced a good homeologous pairing between the chromosomes coming from the diploid species with those of each subgenome (A and B) present in peanut. This aspect is crucial for the transmission of desirable characters from wild diploids into the peanuts subgenomes.

It is worth to mention the importance of the genetic base broadening for peanut obtained by crosses between five distinct diploid species. The most remarkable antecedent is the introgression of resistance to Meloidogyne arenaria (Neal) Chitwood and M. javanica (Treub) Chitwood in the peanut cultivar COAN. As the inheritance of this character is considered as a single, dominant gene (Bendezu and Starr, 2003), it was possible to release the first cultivar that presented a gene located in wild Arachis species and transferred to $A$. hypogaea (Simpson and Starr, 2001). The incorporation of genes from wild species of Arachis to A. hypogaea, in addition to representing a broadening of the genetic base, has contributed to the reduction of production costs, since the introduction of these genes contributes to decrease the inci- 
Table 7 - Polymorphic microsatellite markers used to identify complex hybrids of Arachis. In the genotypes column, the materials are arranged in groups of three (or four) rows, indicating the female (F) and male (M) parents and subsequently the hybrid between these parents tested. Gray colored cells show the alleles shared between the male parent and its hybrid(s).

\begin{tabular}{|c|c|c|c|c|c|c|c|c|c|c|c|c|}
\hline \multicolumn{2}{|c|}{ Genotypes } & \multicolumn{2}{|c|}{ TC7A02 } & \multicolumn{2}{|c|}{ RN2C06 } & \multicolumn{4}{|c|}{ TC6E01 } & \multicolumn{3}{|c|}{$\mathrm{AC} 2 \mathrm{H} 11$} \\
\hline & & a1 & $\mathrm{a} 2$ & a1 & $\mathrm{a} 2$ & a1 & $\mathrm{a} 2$ & a3 & a4 & a1 & a2 & a3 \\
\hline $\mathrm{F}$ & $(\mathrm{K} 30076 \times \mathrm{V} 14167)^{4 \mathrm{x}}$ & 269 & 305 & 200 & & & 160 & 186 & & 213 & 221 & 235 \\
\hline M & $(V 6389 x \text { V9401) })^{4 x}$ & 261 & & 200 & & 158 & 190 & 210 & & & 221 & \\
\hline $\mathrm{H}$ & $\mathrm{HC} 1$ & 273 & 305 & 200 & & 160 & 188 & 210 & & & 221 & 235 \\
\hline $\mathrm{F}$ & $(\mathrm{K} 30076 \times \mathrm{V} 14167)^{4 \mathrm{x}}$ & 269 & 305 & 200 & & 160 & 186 & & & 213 & 221 & 235 \\
\hline M & $(\mathrm{K} 30006 \times \mathrm{V} 6325)^{4 \mathrm{x}}$ & 265 & & 200 & & 192 & 208 & & & 221 & & \\
\hline $\mathrm{H}$ & $\mathrm{HC} 2$ & 265 & 299 & 200 & & 160 & 186 & 192 & 208 & 221 & 235 & \\
\hline $\mathrm{F}$ & $\left(V 6389 x\right.$ V9401) ${ }^{4 x}$ & 261 & & 200 & & 158 & 190 & 210 & & 221 & & \\
\hline M & $(K 30006 x \text { V 6325) })^{4 x}$ & 265 & & 200 & & 192 & 208 & & & 221 & & \\
\hline $\mathrm{H}$ & $\mathrm{HC} 3$ & 263 & 273 & 200 & & 148 & 190 & 208 & & 221 & & \\
\hline $\mathrm{F}$ & $\left(V 6389 x\right.$ V9401) ${ }^{4 x}$ & 261 & & 200 & & 158 & 190 & 210 & & 221 & & \\
\hline M & $(\text { K } 30006 x \text { G 10017) })^{4 x}$ & 265 & & 204 & & 206 & 220 & & & 213 & & \\
\hline $\mathrm{H}$ & $\mathrm{HC} 4$ & 265 & 273 & 200 & 204 & 210 & 220 & & & 221 & & \\
\hline M & $\mathrm{HC} 1$ & 273 & 305 & 200 & & 160 & 188 & 210 & & 221 & 235 & \\
\hline $\mathrm{H}$ & IAC-Tatu-ST x HC1 & 263 & 299 & 200 & & 160 & 186 & 194 & & 221 & & \\
\hline $\mathrm{F}$ & IAC-Tatu-ST & 289 & 299 & 188 & 200 & 160 & 202 & & & 221 & 251 & \\
\hline M & $\mathrm{HC} 2$ & 265 & 299 & 200 & & 160 & 186 & 192 & 208 & 221 & 235 & \\
\hline $\mathrm{H}$ & IAC-Tatu-ST x HC2 & 265 & 305 & 200 & & 160 & & & & 221 & & \\
\hline $\mathrm{F}$ & IAC-Tatu-ST & 289 & 299 & 188 & 200 & 160 & 202 & & & 221 & 251 & \\
\hline M & $\mathrm{HC} 3$ & 263 & 273 & 200 & & 148 & 190 & 208 & & 221 & & \\
\hline $\mathrm{H}$ & IAC-Tatu-ST x HC3 & 289 & 297 & 188 & 200 & 160 & 166 & 202 & & 221 & 251 & \\
\hline $\mathrm{H}$ & IAC-Tatu-ST x HC3 & 289 & 297 & 200 & & 160 & 202 & & & 221 & 251 & \\
\hline $\mathrm{F}$ & IAC-Caiapó & 291 & 299 & 188 & 200 & 160 & 180 & & & 221 & 249 & \\
\hline M & $\mathrm{HC} 1$ & 273 & 305 & 200 & & 160 & 188 & 210 & & 221 & 235 & \\
\hline $\mathrm{H}$ & IAC-Caiapó x HC1 & 289 & 299 & 200 & & 160 & 180 & 188 & & 221 & 249 & \\
\hline $\mathrm{H}$ & IAC-Caiapó x HC2 & 291 & 299 & 188 & 200 & 160 & 180 & & & 221 & 249 & \\
\hline $\mathrm{F}$ & IAC-Caiapó & 291 & 299 & 188 & 200 & 160 & 180 & & & 221 & 249 & \\
\hline M & $\mathrm{HC} 4$ & 265 & 273 & 200 & 204 & 210 & 220 & & & 221 & & \\
\hline $\mathrm{H}$ & IAC-Caiapó x HC4 & 291 & 299 & 188 & 200 & 148 & 160 & 180 & & 221 & 249 & \\
\hline $\mathrm{F}$ & IAC-Runner 886 & 289 & 299 & 188 & 200 & 160 & 194 & & & 221 & & \\
\hline M & $\mathrm{HC} 1$ & 273 & 305 & 200 & & 160 & 188 & 210 & & 221 & 235 & \\
\hline $\mathrm{H}$ & IAC-Runner 886 x HC1 & 261 & 299 & 200 & & 160 & 188 & 194 & & 221 & 251 & \\
\hline $\mathrm{F}$ & IAC-Runner 886 & 289 & 299 & 188 & 200 & 160 & 194 & & & 221 & & \\
\hline M & $\mathrm{HC} 2$ & 265 & 299 & 200 & & 160 & 186 & 192 & 208 & 221 & 235 & \\
\hline $\mathrm{H}$ & IAC-Runner 886 x HC2 & 269 & 299 & 200 & & 160 & 186 & 194 & & 221 & 235 & 251 \\
\hline $\mathrm{H}$ & IAC-Runner 886 x HC2 & 269 & 303 & 200 & & 148 & 160 & 186 & 194 & 221 & 235 & 251 \\
\hline $\mathrm{F}$ & BR1 & 289 & 297 & 188 & 200 & 160 & 200 & & & 221 & 251 & \\
\hline M & $\mathrm{HC} 2$ & 265 & 299 & 200 & & 160 & 186 & 192 & 208 & 221 & 235 & \\
\hline $\mathrm{H}$ & $\mathrm{BR} 1 \times \mathrm{HC} 2$ & 273 & 297 & 200 & & 160 & 186 & 200 & & 221 & 235 & 251 \\
\hline
\end{tabular}

$\mathrm{a}=$ allele Gray data means same alleles between the male parent and the hybrid

dence of diseases and the use of pesticides, thus generating great savings for the producer (Stalker, 2017).

Hybridization and polyploidy usually have been reported as processes that induce genomic and epigenetic rearrangements (Chen, 2007; Madlung and Wendel, 2013). Only few allopolyploids remain as examples that have not undergone conspicuous chromosome rearrangements, among the$\mathrm{m}$ is A. hypogaea (Seijo et al., 2018). The sum of chromo- some markers here analyzed by FISH revealed that the complex amphidiploids showed a high stability in their karyotypes. Arachis hoehnei needs particular attention. Although it was traditionally assumed to belong to the B genome sensu lato because it lacks the A9 pair (Fernández and Krapovickas, 1994), the presence of large heterochromatic bands in its karyotype demonstrates that it may not belong to the B genome species. Therefore, although the genome con- 
Table 8 - Mean damaged area caused by Puccinia arachidis, Anticarsia gemmatalis in the first- and third-instar and degree of damage caused by Spodoptera frugiperda in the first instar in Arachis complex hybrids and Arachis hypogaea cv. IAC Tatu ST.

\begin{tabular}{lcccc}
\hline \multirow{2}{*}{ Genotypes } & P. arachidis & \multicolumn{2}{c}{ A. gemmatalis } & S. frugiperda \\
\cline { 3 - 5 } & & $1^{\text {st }}$ instar & $3^{\text {rd }}$ instar & Leaf damage \\
\hline HC1 & $0.0000^{* *}$ & $1.2650^{* *}$ & $1.7784^{* *}$ & $2 * *$ \\
HC2 & $0.0000^{* *}$ & $\mathrm{NE}$ & $\mathrm{NE}$ & $2 * *$ \\
HC3 & $0.0000^{* *}$ & $0.5344^{* *}$ & $7.0589 * *$ & $1 * *$ \\
HC4 & $0.0144 * *$ & $0.0280^{* *}$ & $5.8682^{* *}$ & $2^{*}$ \\
IAC Tatu ST & 0.2715 & 26.5860 & 20.8090 & 4 \\
\hline
\end{tabular}

** Significant difference between genotype and control at $1 \%$ probability. * Significant difference between genotype and control at $5 \%$ probability. NE - not evaluated

stitution of this species still has to be determined, the accession used here may not be considered as belonging to the $\mathrm{B}$ genome as defined by Robledo and Seijo (2010). From a cytological point of view it may be better placed among the $\mathrm{K}$ genome species.

Concerning the morphological characterization of the germplasm here analyzed, our data demonstrated that the first two principal components explained a high percentage $(>80 \%)$ of the total variance, and that nine characters standout as important in the phenotypic discrimination. This is in complete accordance with previously published results using simple amphidiploids (Fávero et al., 2015; Paula et al., 2017). The fact that the hybrids were morphologically more similar to the amphidiploid progenitors than to the parent $A$. hypogaea (except for the hybrid IAC $503 \times$ (A. gregoryi $\mathrm{V}$ $6389 \times$ A. stenosperma $\mathrm{V} 12488)^{4 \mathrm{x}}$ ) evidenced a high percentage of wild alleles in the progenies, supporting a significant broadening of the peanut gene pool to be used for breeding.

Leaf pests and diseases are among the most important factors that limit the economically sustainable production of peanuts worldwide. Late leaf spot and rust, if not controlled, can cause decreases of up to $70 \%$ in the production and affect speanut quality (Michelotto et al., 2013). The two peanut cultivars used in the present study were chosen because cv. IAC Caiapó is considered the most resistant cultivar to the late leaf spot and rust in the market, but susceptible to the early leaf spot; and cv. BR 1 is susceptible to scab. Despite the partial resistance in IAC Caiapó, all the interspecific hybrids were more resistant than the $A$. hypogaea genotypes included in both the assay done under laboratory and field conditions. Our study confirms that the resistance to these fungi present in wild diploids (Fávero et al., 2009) can be
Table 9 - Evaluation of complex hybrids (HC) and Arachis hypogaea cv. IAC Caiapó for resistance to Puccinia arachidis $(\mathrm{Pa})$, Cercosporidium personatum (Cp), Cercospora arachidicola $(\mathrm{Ca})$, Sphaceloma arachidis (Sa) and total damaged area by foliar fungal diseases.

\begin{tabular}{lccccc}
\hline Genotypes & $\mathrm{Pa}$ & $\mathrm{Cp}$ & $\mathrm{Ca}$ & $\mathrm{Sa}$ & Damaged area \\
\hline $\mathrm{HC} 1$ & $1 * *$ & $3 * *$ & $1 * *$ & $1 * *$ & $0.0139 * *$ \\
$\mathrm{HC} 3$ & $1 * *$ & $2 * *$ & $2 * *$ & $1 * *$ & $0.0142 * *$ \\
$\mathrm{HC} 4$ & $1 * *$ & $3 * *$ & $2 * *$ & $1 * *$ & $0.0097 * *$ \\
$\mathrm{BR} 1$ & $\mathrm{NE}$ & $\mathrm{NE}$ & $\mathrm{NE}$ & 8 & $\mathrm{NE}$ \\
IAC Caiapó & 4 & 5 & 4 & $\mathrm{NE}$ & 0.0658 \\
\hline
\end{tabular}

**Significant difference between genotype and control at $1 \%$ probability. All diseases scored from 1 to 9 . NE- non-evaluated.

introgressed into peanut and, eventually, sources of resistance from different species can be pyramided in elite peanut varieties.

The evaluation of damaged leaf area due to foliar fungal diseases aims at the observation of how much the leaf can be attacked by foliar fungi, regardless of the pathogen. The evaluation was done by the total damaged leaf area. According to data reported by Fávero et al. (2005), in natural infestation under greenhouse conditions greater resistance to late leaf spot and rust was observed in amphidiploid and segregating individuals than in cultivated peanut. In agreement with studies on resistance to leaf spot and rust, resistance to these diseases is polygenic, complex, and probably con-

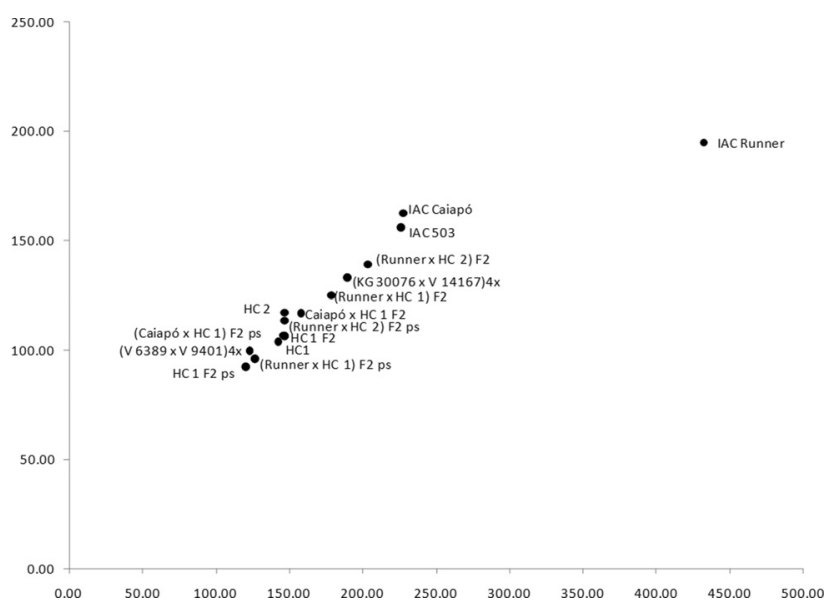

Figure 5 - Biplot graph based on AUDPC and detached leaves evaluation data from parents, $F_{1}$ progenies, $F_{2}$ progenies averages and selected plant of each $\mathrm{F}_{2}$ progeny ( $\mathrm{sp}$ ).
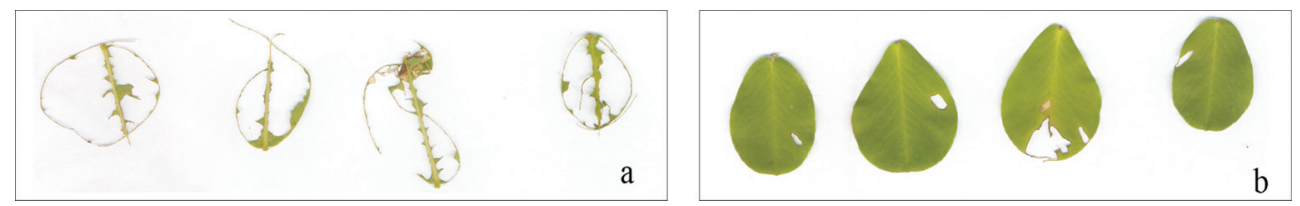

Figure 4 - Evaluation of the damaged leaf area. (a) in the cultivar IAC Tatu ST; (b) in the complex hybrid (Arachis ipaënsis KG $30076 \mathrm{x}$ Arachis duranensis V 14167) x (Arachis gregoryi V 6389 x Arachis linearifoliaV 9401) after four days of inoculation of the velvetbean, Anticarsia gemmatalis in the $1^{\text {st }}$ instar. 
trolled by recessive genes (Dwivedi et al., 2002; Mace et al., 2006; Leal-Bertioli et al., 2010).

Due to the susceptibility to pests, such as thrips (Enneothrips flavens Moulton) and the rednecked peanut worm (Stegasta bosquella (Chambers), peanut production can be severely decreased. This susceptibility is one of the main peanut crop limitations (Lourenção et al., 2007). The use of insect-resistant peanut cultivars may have important benefits, as they keep the pest below the economic damage levels, avoid environment pollution, and reduce the chemical control costs (Lara, 1991). The bioassays here performed, using detached leaves under laboratory conditions to verify the complex hybrids resistance to fall armyworm and velvetbean caterpillar, comparing the complex hybrids with the peanut cultivar IAC Tatu ST, revealed a significant reduction in the damaged leaf area. Moreover, reduction in the growth rate of armyworm caterpillar, when they were fed with complex hybrids leaves, indicates antibiosis resistance. Campos et al. (2011) also verified this type of resistance in some peanut cultivars, but with lower intensity. According to Di Bello (2015), the runner peanut cultivars IAC 147 and IAC Runner 886 have antibiosis resistance that affects the larval survival of $S$. bosquella.

To conclude, it was possible to introgress wild alleles into peanut from non closely related wild diploid species $(A$. gregoryi, A. helodes, and A. hoehnei) by the production of complex hybrids. We demonstrate that it is feasible to introgress genes from distant wild species using complex hybrid developed from a cross between one peanut compatible amphidiploid with another one made by crossing more distant wild species.

\section{Acknowledgments}

This study was funded by Empresa Brasileira de Pesquisa Agropecuária (Embrapa), Coordenação de Aperfeiçoamento de Pessoal de Nível Superior - Brasil (CAPES) Finance Code 001, and Fundação de Apoio a Pesquisa do Distrito Federal (FAP-DF project no. 193.000.184/2004).

\section{Conflict of Interest}

The authors declare that they have no conflict of interest.

\section{Author Contributions}

APF, MDM and JGS conceived and designed the experiments; APF, ARC, IJG, JGS and MDM performed the experiments; APF and MDM analyzed the data; APF, IJG and JGS contributed reagents, materials and/or analysis tools; APF, ARC, MDM, NBD and JGS drafted and wrote the manuscript. All authors approved the final version.

\section{References}

Bendezu IF and Starr JL (2003) Mechanism of resistance to Meloidogyne arenaria in the Peanut Cultivar COAN. J Nematol 35:115-118.
Bertioli DJ, Cannon SB, Froenicke L, Huang G, Farmer AD, Cannon EKS, Liu X, Gao D, Clevenger J, Dash S et al. (2016) The genome sequences of Arachis duranensis and Arachis ipaensis, the diploid ancestors of cultivated peanut. Nat Genet 48:438-446.

Campos AP, Boiça Júnior AL, Jesus FG and Godoy IJ (2011) Avaliação de cultivares de amendoim para resistência a Spodoptera frugiperda. Bragantia 70:349-355.

Chen ZJ (2007) Genetic and epigenetic mechanisms for gene expression and phenotypic variation in plant polyploids. Annu Rev Plant Biol 58:377-406.

Custodio A, Seijo JG and Valls JFM (2013) Characterization of Brazilian accessions of wild Arachis species of section Arachis (Fabaceae) using heterochromatin detection and fluorescence in situ hybridization (FISH). Genet Mol Biol 36:364-370.

Di Bello MM, Souza BHS, Janini JC and Boiça Junior AL (2015) Não preferência para alimentação e antibiose em cultivares de amendoim a Stegasta bosquella (Chambers) (Lepidoptera: Gelechiidae). Semin-Cienc Agrar 36:619-630.

Dwivedi SL, Pande S, Rao JN and Nigam SN (2002) Components of resistance to late leaf spot and rust among interspecific derivatives and their significance in a foliar disease resistance breeding in groundnut (Arachis hypogaea L.). Euphytica 125:81-88.

Fávero AP, Nass LL, Cargnin A and Leonardecz Neto E (2005) Rooting performance from leaf petioles of accessions and hybrids of wild Arachis species. Sci Agric 62:62-68.

Fávero AP, Simpson CE, Valls JFM and Vello NA (2006) Study of the evolution of cultivated peanut through crossability studies among Arachis ipaënsis, A. duranensis and A. hypogaea. Crop Sci 46:1546-1552.

Fávero AP, Pádua JG and Costa TS (2015) New hybrids from peanut (Arachis hypogaea L.) and synthetic amphidiploid crosses show promise in increasing pest and disease tolerance. Genet Mol Res 14:16694-16703.

Fávero AP, Moraes SAD, Garcia AAF, Valls JFM and Vello NA (2009) Characterization of rust, early and late leaf spot resistance in wild and cultivated peanut germplasm. Sci Agr 66:110-117.

Fernández A and Krapovickas A (1994) Cromosomas y evolucion en Arachis (Leguminosae). Bonplandia 8:187-220.

Freitas FO, Moretzsohn MC and Valls JFM (2007) Genetic variability of Brazilian Indian landraces of Arachis hypogaea L. Genet Mol Res 6:675-684.

Janini JC, Boiça Junior AL, Godoy IJ, Michelotto MD and Fávero AP (2010) Avaliação de espécies silvestres e cultivares de amendoim para resistência a Enneothrips flavens Moulton. Bragantia 69:891-898.

Krapovickas A and Gregory WC (1994) Taxonomia del gênero Arachis (Leguminosae). Bonplandia 8:1-186.

Kochert G, Stalker HT, Gimenes MA, Galgaro L, Lopes CR and Moore K (1996) RFLP and cytogenetic evidence on the origin and evolution of allotetraploid domesticated peanut Arachis hypogaea (Leguminosae). Am J Bot 83:1282-1291.

Lara FM (1991) Princípios de resistência de plantas a insetos. Ícone, São Paulo.

Lavia GI (1998) Karyotypes of Arachis palustris and A. praecox (section Arachis), two species with basic chromosome number $\mathrm{x}=9$. Cytologia 63:177-181.

Leal-Bertioli SC, Farias MP and Silva PIT (2010) Ultrastructure of the initial interaction of Puccinia arachidis and Cercosporidium personatum with leaves of Arachis hypogaea and Arachis stenosperma. J Phytopathol 158:792-796. 
Leal-Bertioli SCM, Cavalcante U, Gouveia EG, Ballen-Taborda C, Shirasawa K, Guimaraes PM, Jackson SA, Bertioli DJ and Moretzsohn MC (2015) Identification of QTLs for rust resistance in the peanut wild species Arachis magna and the development of KASP markers for marker assisted selection. G3 (Bethesda) 5:1403-1413.

Lourenção AL, Moraes ARA, Godoy IJ and Ambrasano GMB (2007) Efeito da infestação de Enneothrips flavens Moulton sobre o desenvolvimento de cultivares de amendoim. Bragantia 66:623-636.

Mace ES, Phong DT, Upadhyaya HD, Chandra S and Crouch JH (2006) SSR analysis of cultivated groundnut (Arachis hypogaea L.) germplasm resistant to rust and late leaf spot diseases. Euphytica 152:317-330.

Madlung A and Wendel JF (2013) Genetic and epigenetic aspects of polyploid evolution in plants. Cytogenet Genome Res 140:270-285.

Michelotto MD, Godoy IJ and Fávero AP (2013) Espécies silvestres como fontes de resistência a pragas e doenças do amendoim. Pesqui Tecnol 10:1-7.

Michelotto MD, Barioni Jr W, de Resende MDV, Godoy IJ, Leonardecz E and Fávero AP (2015) Identification of fungus resistant wild accessions and interspecific hybrids of the genus Arachis. PLoS One 10:e0128811.

Michelotto MD, Godoy IJ, Santos JF, Martins ALM, Leonardecz E and Fávero AP (2016) Identifying amphidiploids resistant to foliar fungal diseases. Crop Sci 56:1792-1798.

Michelotto MD, de Godoy IJ, Pirotta MZ, dos Santos JF, Finoto EL and Fávero AP (2017) Resistance to thrips (Enneothrips flavens) in wild and amphidiploid Arachis species. PLoS One 12:e176811.

Moraes SDA and Salgado CL (1982) Utilização da técnica de folhas destacadas de amendoim (Arachis hypogaea L.) para inoculações com Cercospora arachidicola Hori e Cercospora personata (Bert. \& Curt.) Ell. \& Ev. Summa Phytopathol 8:39-55.

Moretzsohn MC, Gouveia EG, Inglis PW, Leal-Bertioli SCM, Valls JFM and Bertiolli DJ (2013) A study of the relationships of cultivated peanut (Arachis hypogaea) and its most closely related wild species using intron sequences and microsatellite markers. Ann Bot-London 111:113-126.

Moscone EA, Matzke MA and Matzke AJM (1996) The use of combined FISH/GISH in conjuction with DAPI counterstaining to identify chromosomes containing transgene inserts in amphidiploid tobacco. Chromosoma 105:321-326

Pande S and Rao JN (2001) Resistance of wild Arachis species to late leaf spot and rust in greenhouse trials. Plant Dis 85:851-855.

Paula AF, Dinato NB, Vigna BBZ and Fávero AP (2017) Recombinants from the crosses between amphidiploid and cultivated peanut (Arachis hypogaea) for pest-resistance breeding programs. PLoS One 12:e0175940.

Peñaloza A and Valls JFM (2005) Chromosome number and satellite chromosome morphology of eleven species of Arachis (Leguminosae). Bonplandia 14:65-72.

Robledo G and Seijo JG (2008) Characterization of Arachis D genome using physical mapping of heterochromatic regions and rDNA loci by FISH. Genet Mol Biol 31:717-724.

Robledo G and Seijo G (2010) Species relationships among the wild B genome of Arachis species (section Arachis) based on FISH mapping of rDNA loci and heterochromatin detection: a new proposal for genome arrangement. Theor Appl Genet 121:1033-1046.
Robledo G, Lavia GI and Seijo G (2009) Species relations among wild Arachis species with the A genome as revealed by FISH mapping of rDNA loci and heterochromatin detection. Theor Appl Genet 118:1295-1307.

Santana SH and Valls JF (2015) Arachis veigae (Fabaceae), the most dispersed wild species of the genus, and yet taxonomically overlooked. Bonplandia 24:139-150.

Seijo JG, Lavia GI, Fernández A, Krapovickas A, Ducasse D and Moscone EA (2004) Physical mapping of the 5S and 18S-25S rRNA genes by FISH as evidence that Arachis duranensis and A. ipaensis are the wild diploid progenitors of A. hypogaea (Leguminosae). Am J Bot 91:1294-1303.

Seijo JG, Kovalsky EI, Chalup LMI, Samoluk SS, Fávero A and Robledo GA (2018) Karyotype stability and genome-specific nucleolar dominance in peanut, its wild 4 ancestor, and a synthetic AABB polyploid. Crop Sci 58:1671-1683.

Simpson CE (2001) Use of wild Arachis species introgression of genes into A. hypogaea. Peanut Sci 28:114-116.

Simpson CE and Starr JL (2001) Registration of 'COAN' peanut. Crop Sci 41:918-931.

Silvestri MC, Ortiz AM and Lavia GI (2015) rDNA loci and heterochromatin positions support a distinct genome type for 'x=9 species' of section Arachis (Arachis, Leguminosae). Plant Syst Evol 301:555-562.

Stalker TH (2017) Utilizing wild species for peanut improvement. Crop Sci 57:1102-1120.

Stalker HT, Tallury SP, Seijo GR and Leal-Bertioli SC (2016) Biology, speciation, and utilization of peanut species. In: Stalker HT and Wilson RF (eds) Peanuts: Genetics, Processing, and Utilization. AOCS Press, Urbana, pp 27-66.

Subrahmanyam P, McDonald D, Gibbons RW, Nigam SN and Nevill DJ (1982) Resistance to rust and late leaf spot diseases in some genotypes of Arachis hypogaea. Peanut Sci 9:9-14.

Valls JFM and Simpson CE (2005) New species of Arachis (Leguminosae) from Brazil, Paraguay and Bolivia. Bonplandia 14:35-63.

Valls JFM and Simpson CE (2017) A new species of Arachis (Fabaceae) from Mato Grosso, Brazil, related to Arachis matiensis. Bonplandia 26:143-149.

Valls JFM, Costa LC and Custodio AR (2013) A novel trifoliolate species of Arachis (Fabaceae) and further comments on the taxonomic section Trierectoides. Bonplandia 22:91-97.

Varman PV (2001a) Breeding behavior of triploids in back crosses with Arachis hypogaea. Madras Agric J 88:375-378.

Varman P (2001b) Interspecific gene transfer form Arachis correntina into A. hypogaea. Ann Agric Res 22:225-228.

Zhou X, Xia Y, Liao J, Liu K, Li Q, Dong Y, Ren X, Chen Y, Huang L, Liao B et al. (2016) Quantitative trait locus analysis of late leaf spot resistance and plant-type-related traits in cultivated peanut (Arachis hypogaea L.) under multi-environments. PLoS One 11:e0166873.

\section{Internet Resources}

USDA (2016) Unites States Department of Agriculture, https:/apps.fas.usda.gov/psdonline/circulars/production.pdf (accessed 12 September 2016).

Associate Editor: Marcio C. Silva-Filho

License information: This is an open-access article distributed under the terms of the Creative Commons Attribution License (type CC-BY), which permits unrestricted use, distribution and reproduction in any medium, provided the original article is properly cited. 